\title{
PENINGKATAN KEMAMPUAN KONEKSI MATEMATIS MAHASISWA MELALUI PEMBELAJARAN MODEL SIKLUS 7E BERBANTUAN HYPNOTEACHING
}

\author{
${ }^{1}$ Hairul Saleh, ${ }^{2}$ Warsito \\ ${ }^{1,2}$ Universitas Muhammadiyah Tangerang, J1. Perintis Kemerdekaan I/33, Cikokol, Kota Tangerang, Banten, \\ Indonesia \\ e-mail: kshairul@gmail.com
}

\begin{abstract}
Abstrak
Tujuan penelitian ini mengkaji pembelajaran dengan model siklus 7E berbantuan hypnoteaching dalam meningkatkan kemampuan koneksi matematis mahasiswa. Penelitian ini merupakan penelitian quasi eksperimen. Desain dalam penelitian ini adalah desain kelompok kontrol pretes-postes. Kelas eksperimen diberi pembelajaran model siklus 7E berbantuan hypnoteaching dan kelas kontrol diberi pembelajaran konvensional. Populasi dalam penelitian ini adalah mahasiswa Program Studi Pendidikan Matematika pada salah satu Universitas di kota Tangerang. Analisis statistika yang digunakan dalam penelitian ini adalah uji-t dan uji Mann-Whitney. Hasil penelitian menunjukkan bahwa peningkatan kemampuan koneksi matematis mahasiswa yang mendapatkan pembelajaran model siklus 7E berbantuan hypnoteaching lebih baik daripada mahasiswa yang mendapatkan pembelajaran konvensional.
\end{abstract}

Kata Kunci: kemampuan koneksi matematis, pembelajaran siklus 7E, hypnoteaching

\begin{abstract}
The aim of this research was to find out whether 7E learning cycle under hypnoteaching model can enhance students' mathematical connection skill. This research was quasi experimental study. The design of this study was pretest-posttest control group design. There were two groups of samples used in the study. The experimental group was given 7E learning cycle under hypnoteaching model, while the control group was given conventional model. The population of this studi was the student of mathematics education program in one university in Tangerang. The statistical analysis used to test the hypothesis of this study were t-test and mann-whitney U. The result of this study shows that the students' achievement of mathematical connection skill who obtained 7E learning cycle under hypnoteaching model are higher than the students who obtained conventional model.
\end{abstract}

Keywords: students' mathematical connection skill, 7E learning cycle, hypnoteaching

\section{PENDAHULUAN}

\section{Latar Belakang}

Kemampuan koneksi matematis merupakan salah satu kemampuan matematis yang harus dimiliki siswa. National Council of Teacher of Mathematics (NCTM, 2003:29) menyebutkan bahwa standar proses dalam pembelajaran matematika meliputi kemampuan pemecahan masalah (problem solving), kemampuan penalaran (reasoning), kemampuan komunikasi (communication), kemampuan membuat koneksi (connection), dan kemampuan representasi (representation).

Kerangka Kualifikasi Nasional Indonesia (KKNI) menyatakan bahwa lulusan sarjana harus mampu menguasai konsep teoritis bidang pengetahuan dan keterampilan tertentu secara umum dan konsep teoritis bagian khusus dalam bidang pengetahuan dan keterampilan tersebut 
secara mendalam. Unsur pengetahuan harus menunjukkan cabang ilmu yang dikuasai yaitu berkaitan dengan materi matematika. Pengetahuan yang harus dimiliki oleh mahasiswa matenatika harus luas dan mendalam sehingga mahasiswa harus mampu dalam mengkoneksikan ide atau gagasan dan mampu menyelesaikan masalah sampai mencapai tujuan. Oleh karena itu kemampuan yang dibekali kepada mahasiswa dan berkaitan dengan pengetahuan yang harus dikuasai salah satunya adalah kemampuan koneksi matematis.

Koneksi matematis merupakan kecakapan mahasiswa dalam mengungkapkan dan menghubungkan ide-ide matematika secara lisan, tertulis, gambar, diagram, menggunakan benda nyata, atau menggunakan simbol matematika. Mahasiswa yang memiliki kemampuan untuk mengkoneksikan ide atau gagasan matematisnya dengan baik cenderung mempunyai pemahaman yang baik terhadap konsep yang dipelajari dan mampu memecahkan permasalahan yang berkaitan dengan konsep yang dipelajari. Matematika adalah bidang studi yang terpadu, bukan sekumpulan bagian-bagian yang saling terpisah, walaupun seringkali disajikan dalam bentuk seperti ini. Kemampuan koneksi matematika penting bagi mahasiswa karena koneksi antar ide-ide matematika dapat membuat pemahaman mahasiswa lebih lama dan lebih dalam. Koneksi dapat mengantarkan mahasiswa belajar kegunaan dari matematika.

Berdasarkan hasil obeservasi terhadap mahasiswa menunjukkan bahwa kemampuan koneksi matematis mahasiswa masih rendah. Sebagai ilustrasi dapat dilihat pada hasil pekerjaan mahasiswa materi kalkulus integral seperti pada Gambar 1.

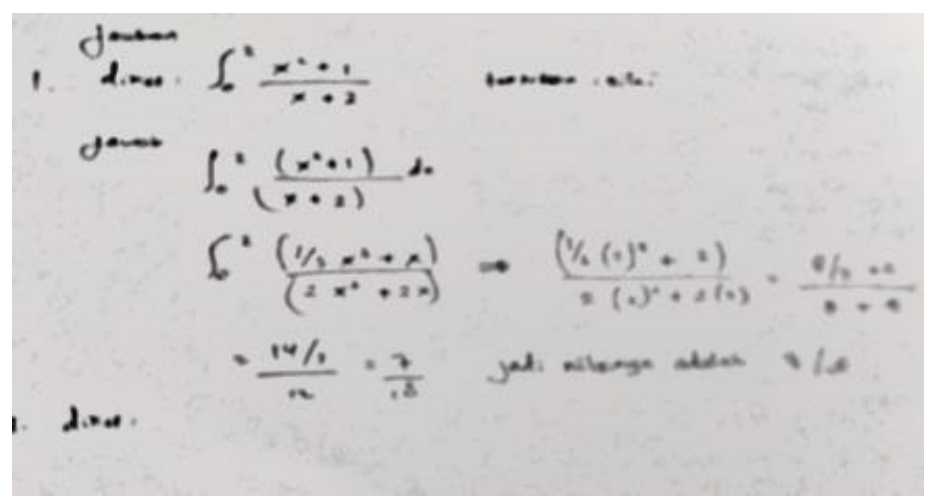

Gambar 1. Hasil Pekerjaan Mahasiswa dalam Kemampuan Koneksi Matematika

Jawaban di atas menunjukkan bahwa mahasiswa tidak memahami hubungan antara konsep pengintegralan dengan konsep fungsi rasional. Soal di atas berhubungan dengan materi pengintegralan fungsi rasional tidak sejati karena pembilang merupakan fungsi dengan pangkat lebih dari pangkat fungsi pada penyebut. Terlihat mahasiswa langsung mengintegralkan bagian pembilang dan bagian penyebut. Seharusnya mahasiswa membagi pembilang dengan penyebut

Peningkatan Kemampuan Koneksi Matematis Mahasiswa Melalui Pembelajaran Model Siklus $7 E$ Berbantuan Hypnoteaching Saleh, Warsito 
lebih dahulu sehingga akhirnya diperoleh sebuah polinom ditambah sisa yang merupakan fungsi rasional sejati.

Oleh karena itu, untuk memperbaiki kondisi yang demikian maka dosen sebagai fasilitator sebaiknya memiliki kemampuan untuk menciptakan situasi belajar yang melibatkan mahasiswa secara aktif sehingga bermuara pada peningkatan kemampuan matematis mahasiswa, khususnya kemampuan koneksi matematis. Upaya yang dapat dilakukan antara lain dengan menerapkan model pembelajaran yang tepat dan lebih bermakna yakni model pembelajaran yang melibatkan mahasiswa dalam pembelajaran, salah satu model pembelajaran adalah siklus pembelajaran (learning cycle).

Siklus belajar merupakan salah satu model pembelajaran yang menganut paham konstruktivis dalam belajar. Dasar pemikiran para konstruktivis adalah proses pembelajaran yang efektif menghendaki agar dosen mengetahui bagaimana mahasiswa mendatangkan fakta dan fenomena yang menjadi subjek pembelajaran. Implementasi model ini dalam kegiatan belajar dapat membantu mahasiswa memahami konsep melalui tahap pengumpulan data (exploration), pengenalan konsep (concept introduction), dan penerapan konsep (concept application). Tiga siklus (fase) tersebut telah dikembangkan menjadi lima tahap yang terdiri dari engagement, exploration, explanation, elaboration, dan evaluation (Lorsbach, 2002), dan sekarang dikembangkan lagi menjadi tujuh siklus (fase) yang terdiri dari elicit, engagement, exploration, explanation, elaboration, evaluation dan extend (Eisenkraft, 2003). Dalam penelitian ini akan digunakan siklus pembelajaran 7E yakni elicit, engagement, exploration, explanation, elaboration, evaluation dan extend.

Model pembelajaran 7E melatih mahasiswa untuk melakukan identifikasi terhadap suatu permasalahan matematis, mengoneksikan pemahaman matematis yang dimiliki, mengungkapkan pendapat, bertanya, mempresentasikan dan menjelaskan jawaban, memformulasikan kembali konsep matematis dengan bahasanya sendiri, menyelesaikan soalsoal tantangan, melakukan evaluasi serta mengembangkan jawaban-jawaban yang lebih inovatif. Dosen sebagai fasilitator mahasiswa dalam belajar, membimbing dan mengarahkan mahasiswa selama proses pembelajaran. Pendapat atau ide yang dimunculkan mahasiswa, diapresiasi dengan baik oleh dosen, sehingga mahasiswa merasa dirinya mempunyai kontribusi terhadap pembelajaran di kelas. Apabila kondisi pembelajaran seperti ini terus menerus diciptakan, mahasiswa dapat melatih dan mengembangkan kemampuan koneksi matematisnya.

Hypnoteaching adalah cara mengajar yang unik, kreatif sekaligus imajinatif yang dapat membuat mahasiswa merasa nyaman dalam proses belajar mengajar, sejak materi dimulai 
hingga materi diakhiri yang dilakukan dengan menggunakan bahasa-bahasa bawah sadar yang menimbulkan sugesti mahasiswa untuk berkonsentrasi secara penuh pada proses pembelajaran. Hypnoteaching adalah seni berkomunikasi dengan jalan memberikan sugesti agar para mahasiswa menjadi lebih cerdas. Dengan sugesti yang diberikan diharapkan mereka tersadar dan tercerahkan bahwa ada potensi luar biasa yang selama ini belum pernah mereka optimalkan dalam pembelajaran. Dengan memanfaatkan hypnoteaching diharapkan hambatan atau kesulitan yang dihadapi mahasiswa dalam setiap siklus pada siklus pembelajaran 7E dapat diatasi. Hypnoteaching memasukkan ke dalam pikiran bawah sadar mahasiswa bahwa mereka mampu meningkatkan kemampuan matematika mereka termasuk kemampuan koneksi matematis.

Pada proses pembelajaran, kemampuan mahasiswa dalam koneksi matematis akan berbeda-beda sesuai dengan pengetahuan yang telah dimiliki yaitu pengetahuan awal matematis. Pembelajaran dengan siklus pembelajaran 7E berbantuan hypnoteaching akan mengantisipasi respon mahasiswa yang akan muncul dari perbedaan pengetahuan awal matematis. Berdasarkan uraian di atas, penulis terdorong untuk melakukan penelitian dengan judul "Peningkatan Kemampuan Koneksi Matematis Mahasiswa Melalui Pembelajaran Model Siklus 7E Berbantuan Hypnoteaching".

\section{Rumusan Masalah}

Berdasarkan latar belakang masalah yang telah dikemukakan di atas, maka penulis merumuskan masalah yang diteliti sebagai berikut:

"Apakah peningkatan kemampuan koneksi matematis mahasiswa yang mendapat pembelajaran siklus 7E berbantuan hypnoteaching lebih baik daripada mahasiswa yang mendapat pembelajaran konvensional?"

\section{Tujuan Penelitian}

Secara umum tujuan penelitian ini adalah mengkaji secara mendalam peningkatan kemampuan koneksi matematis mahasiswa yang memperoleh pembelajaran siklus 7E berbantuan hypnoteaching. Dengan demikian, penelitian ini diarahkan untuk menginvestigasi kemampuan koneksi matematis mahasiswa yang memperoleh pembelajaran siklus 7E berbantuan hypnoteaching.

\section{Kemampuan Koneksi Matematis}

Menurut NCTM (National Council of Teacher of Mathematics) (2003: 64), indikator untuk kemampuan koneksi matematika yaitu: (a) Mengenali dan memanfaatkan hubunganhubungan antara gagasan dalam matematika; (b) Memahami bagaimana gagasan-gagasan 
dalam matematika saling berhubungan dan mendasari satu sama lain untuk menghasilkan suatu keutuhan koheren; (c) Mengenali dan menerapkan matematika dalam kontek-konteks di luar matematika. Penjelasan untuk indikator-indikator tersebut adalah sebagai berikut:

a. Mengenali dan memanfaatkan hubungan-hubungan antara gagasan dalam matematika. Dalam hal ini, koneksi dapat membantu mahasiswa untuk memanfaatkan konsep-konsep yang telah mereka pelajari dengan konteks baru yang akan dipelajari oleh mahasiswa dengan cara menghubungkan satu konsep dengan konsep lainnya sehingga mahasiswa dapat mengingat kembali tentang konsep sebelumnya yang telah mahasiswa pelajari, dan mahasiswa dapat memandang gagasan-gagasan baru tersebut sebagai perluasan dari konsep matematika yang sudah dipelajari sebelumnya.

Mahasiswa mengenali gagasan dengan meuliskan apa yang diketahui dan ditanyakan dalam menjawab soal dan mahasiswa memanfaatkan gagasan dengan menuliskan gagasangagasan tersebut untuk membuat model matematika yang digunakan dalam menjawab soal.

b. Memahami bagaimana gagasan-gagasan dalam matematika saling berhubungan dan mendasari satu sama lain untuk menghasilkan suatu keutuhan koheren.

Pada tahap ini mahasiswa mampu melihat struktur matematika yang sama dalam setting yang berbeda, sehingga terjadi peningkatan pemahaman tentang hubungan antar satu konsep dengan konsep lainnya.

c. Mengenali dan menerapkan matematika dalam konteks-konteks di luar matematika.

Konteks-konteks eksternal matematika pada tahap ini berkaitan dengan hubungan matematika dengan kehidupan sehari-hari, sehingga mahasiswa mampu mengkoneksikan antara kejadian yang ada pada kehidupan sehari-hari (dunia nyata) ke dalam model matematika.

Menurut Sumarmo (2003), kemampuan koneksi matematika dapat dilihat dari indikatorindikator berikut: (1) mengenali representasi ekuivalen dari konsep yang sama; (2) mengenali hubungan prosedur matematika suatu representasi keprosedur representasi yang ekuivalen; (3) menggunakan dan menilai keterkaitan antar topik matematika dan keterkaitan diluar matematika; dan (4) menggunakan matematika dalam kehidupan sehari-hari.

Berdasarkan kajian teori di atas, secara umum terdapat tiga aspek kemampuan koneksi matematika, yaitu:

1) Menuliskan masalah kehidupan sehari-hari dalam bentuk model matematika.

Pada aspek ini, diharapkan mahasiswa mampu mengkoneksikan antara masalah pada kehidupan sehari-hari dan matematika. 
2) Menuliskan konsep matematika yang mendasari jawaban.

Pada aspek ini, diharapkan mahasiswa mampu menuliskan konsep matematika yang mendasari jawaban guna memahami keterkaitan antar konsep matematika yang akan digunakan.

3) Menuliskan hubungan antar obyek dan konsep matematika.

Pada aspek ini, diharapkan mahasiswa mampu menuliskan hubungan antar konsep matematika yang digunakan dalam menjawab soal yang diberikan.

\section{Pembelajaran Siklus 7E}

Model siklus pembelajaran 5E membutuhkan instruksi untuk memasukkan masingmasing unsur berikut: engage (melibatkan), explore (mengeksplorasi), explain (menjelaskan), elaborate (menggunakan), dan evaluate (mengevaluasi). Model 7E yang diusulkan memperluas unsur engage menjadi dua komponen yaitu elicit (mendatangkan) dan engage (melibatkan). Demikian pula, model 7E memperluas tahap elaborate dan evaluate ke dalam tiga komponen - elaborate, evaluate dan extend (memperluas).

Perubahan ini tidak dimaksudkan untuk menambah kompleksitas melainkan untuk memastikan pendidik tidak menghilangkan unsur penting dalam belajar pada pembelajaran mereka dengan anggapan yang salah bahwa mereka memenuhi persyaratan siklus belajar.

Penelitian saat ini dalam ilmu kognitif telah menunjukkan bahwa memunculkan pemahaman sebelumnya adalah komponen penting dari proses pembelajaran. Penelitian juga menunjukkan bahwa mahasiswa yang terlatih jauh lebih mahir dalam transfer belajar dari pemula dan praktek transfer belajar diperlukan dalam pengajaran yang baik (Bransford, Brown dan Cocking 2000 dalam Eisenkraft 2003).

Komponen engage dalam model 5E ini dimaksudkan untuk memusatkan perhatian mahasiswa, menyiapkan mahasiswa berpikir tentang materi pelajaran, memunculkan pertanyaan pada pikiran mahasiswa, merangsang pemikiran dan mengakses pengetahuan sebelumnya. Komponen engage mencakup mengakses pengetahuan sebelumnya dan memunculkan antusiasme terhadap materi pelajaran. Pendidik dapat membangkitkan mahasiswa, membuat mereka tertarik dan siap untuk belajar serta percaya bahwa mereka memenuhi fase siklus engage ini, tanpa mengabaikan kebutuhan untuk mencari tahu apa pengetahuan sebelumnya yang membawa ke topik baru. Memunculkan pemahaman sebelumnya dalam memastikan apa yang mahasiswa ketahui sebelum pelajaran dimulai sangatlah penting. Menyadari bahwa mahasiswa mengkonstruksi pengetahuan dari pengetahuan yang ada, pendidik perlu mencari tahu apa pengetahuan yang ada pada mahasiswa 
mereka. Kegagalan untuk melakukannya dapat mengakibatkan mahasiswa mengembangkan konsep yang sangat berbeda dari yang pendidik maksudkan (Bransford, Brown, dan Cocking 2000 dalam Eisenkraft 2003).

Ekspansi model 5E tidak menggantikan komponen engage dengan komponen elicit; komponen engage masih merupakan elemen penting dalam pembelajaran. Tujuannya adalah untuk terus menarik minat mahasiswa dengan cara apa pun yang mungkin dan untuk mengidentifikasi konsepsi sebelumnya. Oleh karena itu komponen elicit harus berdiri sendiri sebagai pengingat penting dalam belajar dan membangun makna.

Tahap explore pada siklus pembelajaran memberikan kesempatan bagi mahasiswa untuk mengamati, merekam data, mengisolasi variabel, mendesain dan merencanakan percobaan, membuat grafik, menginterpretasikan hasil, mengembangkan hipotesis, dan mengorganisasikan temuan mereka. Pendidik dapat menyusun pertanyaan, menyarankan pendekatan, memberikan umpan balik dan menilai pemahaman.

Mahasiswa diperkenalkan dengan model, hukum, dan teori-teori selama fase explain dalam siklus belajar. Mahasiswa merangkum hasil dalam hal ini teori-teori dan model baru. Dosen membimbing mahasiswa menuju generalisasi yang koheren dan konsisten, membantu mahasiswa dengan kosa kata ilmiah yang berbeda, dan memberikan pertanyaan yang membantu mahasiswa menggunakan kosa kata ini untuk menjelaskan hasil eksplorasi mereka. Perbedaan antara komponen explore dan explain memastikan bahwa konsep mendahului terminologi.

Tahap elaborate dari siklus pembelajaran memberikan kesempatan bagi mahasiswa untuk menerapkan pengetahuan mereka pada domain baru, yang mungkin termasuk memunculkan pertanyaan dan hipotesis baru untuk mengeksplorasi. Fase ini juga termasuk terkait masalah numerik bagi mahasiswa untuk dipecahkan. Tahap elaborate berhubungan langsung dengan konstruksi psikologis yang disebut "transfer belajar". Pendidikan tinggi diciptakan dengan harapan bahwa penggunaan pengetahuan yang lebih umum akan ditemukan di luar pendidikan tinggi dan setelah keluar dari pendidikan tinggi. Transfer belajar dapat berkisar dari transfer satu konsep ke konsep lain; satu pelajaran ke pelajaran lain; dan dari pendidikan tinggi untuk kegiatan di luar pendidikan tinggi.

Penambahan fase expand pada fase elaborate dimaksudkan untuk secara eksplisit mengingatkan pendidik pentingnya bagi mahasiswa untuk berlatih transfer belajar. Pendidik perlu memastikan bahwa pengetahuan diterapkan dalam konteks yang baru dan tidak terbatas pada elaborasi sederhana. 
Tahap evaluate pada siklus belajar mencakup evaluasi formatif dan sumatif. Jika pendidik benar-benar menghargai siklus belajar dan eksperimen mahasiswa di kelas maka pendidik harus menyertakan aspek investigasi tersebut pada tes. Pengujian harus mencakup pertanyaan dari eksperimen dan harus menamyakan mahasiswa tentang kegiatan eksperimen. Mahasiswa diminta menginterpretasikan data dari eksperimen yang telah diselesaikan. Mahasiswa juga harus diminta untuk merancang eksperimen sebagai bagian dari penilaian mereka.

Evaluasi formatif tidak boleh terbatas pada tahap tertentu dari siklus. Siklus ini tidak harus linier. Evaluasi formatif harus dilakukan selama semua interaksi dengan mahasiswa. Tahap elicit adalah evaluasi formatif. Fase explore dan explain harus selalu disertai dengan teknik pemeriksaan pendidik terhadap pemahaman mahasiswa.

Mengganti elaborate dan evaluate dengan elaborate, expand dan evaluate adalah cara untuk menekankan bahwa transfer belajar, seperti yang dipersyaratkan dalam fase expand, juga dapat digunakan sebagai bagian dari tahap evaluasi dalam siklus belajar. Pengadopsian model 7E memastikan bahwa memunculkan pemahaman terdahulu dan kesempatan untuk transfer belajar tidak dihilangkan.

\section{Hypnoteaching}

Menurut Hajar (2011) hypnoteaching adalah seni berkomunikasi dengan jalan memberikan sugesti agar para mahasiswa menjadi lebih cerdas. Dengan sugesti yang diberikan diharapkan mereka tersadar dan tercerahkan bahwa ada potensi luar biasa yang selama ini belum pernah mereka optimalkan dalam pembelajaran. Menurutnya pendidik harus menguasai langkah-langkah dasar hypnoteahing sebagai berikut:

1) Niat dan motivasi dalam diri sendiri

Niat yang besar akan memunculkan motivasi yang tinggi dan komitmen untuk concern dan survive pada bidang yang ditekuni.

2) Pacing

Pacing berarti menyamakan posisi, gerak tubuh, bahasa, serta gelombang otak dengan orang lain atau mahasiswa. Setelah melakukan pacing para mahasiswa akan merasa nyaman dengan pendidik.

\section{3) Leading}

Leading memiliki pengertian memimpin atau mengarahkan sesuatu. Karena dilakukan setelah pacing maka hampir setiap apapun yang pendidik ucapkan atau tugaskan kepada mahasiswa akan dilakukan dengan suka rela dan bahagia. 
4) Gunakan kata positif.

Penggunaan kata positif adalah langkah pendukung dalam melakukan pacing dan leading.

Penggunaan kata positif ini sesuai dengan cara kerja pikiran bawah sadar yang tidak mau menerima kata negatif.

5) Berikan pujian

Pujian merupakan salah satu cara untuk membentuk konsep diri seseorang. Pujian yang tulus akan mendorong mahasiswa melakukan sesuatu yang lebih baik dari sebelumnya.

6) Modeling

Modeling adalah proses memberi teladan atau contoh melalui ucapan dan perilaku yang konsisten dan merupakan salah satu kunci keberhasilan hypnoteaching.

Hypnoteaching menurut Noer (2010) adalah proses pengajaran yang dapat memberikan sugesti kepada para mahasiswa. Hypnoteaching lebih banyak mengambil peranan pikiran bawah sadar. Frekuensi gelombang otak yang dipakai adalah alpha dan theta yang akan memproduksi hormon serotonin dan endorfin. Otak akan mengeluarkan hormon yang menyebabkan seseorang merasa nyaman,pikirannya sangat hening dan khusuk, hatinya merasa tenang, serta bahagia dalam hidupnya.

Berdasarkan beberapa pendapat tentang pengertian hypnoteaching, Ginting (2013) menyimpulkan bahwa hypnoteaching adalah cara mengajar yang unik, kreatif sekaligus imajinatif yang dapat membuat mahasiswa merasa nyaman dalam proses belajar mengajar, sejak pelajaran dimulai hingga pelajaran diakhiri yang dilakukan dengan menggunakan bahasa-bahasa bawah sadar yang menimbulkan sugesti mahasiswa untuk berkonsentrasi secara penuh pada ilmu yang disampaikan oleh pendidik.

Kurniawati (2014) menyimpulkan bahwa hypnoteaching adalah metode pembelajaran yang mengupayakan penurunan frekuensi gelombang otak dengan membuat mahasiswa fokus (focusing), baik dengan tayangan video, cerita inspiratif, maupun yelling dan menggunakan rileksasi dan imaginasi sehingga perhatian mahasiswa menjadi terpusat, mahasiswa menjadi rileks dan lebih sugestif dalam menangkap nilai-nilai positif dari sebuah proses pembelajaran.

\section{Pembelajaran Siklus 7E Berbantuan Hypnoteaching}

Siklus belajar merupakan pendekatan pengajaran yang aktif berdasarkan teori Piaget tentang perkembangan mental dan konstruktivisme. Melalui pengembangan oleh para peneliti untuk waktu yang lama, model siklus belajar datang dalam tiga jenis, tergantung pada jumlah fase yang dikandungnya (4,5 atau 7). Versi terbaru memiliki 7 tahap berikut: 
elicit (mendatangkan), engage (melibatkan), explore (mengeksplorasi), explain (menjelaskan), elaborate (menggunakan), evaluate (mengevaluasi) dan extend (memperluas). Penelitian telah menunjukkan bahwa pembelajaran model siklus berpengaruh positif pada produk pembelajaran tertentu, terbukti menjadi alat yang penting untuk mengajarkan konsep, mempengaruhi prestasi akademik mahasiswa dengan cara yang positif, memungkinkan mahasiswa untuk mengembangkan atau meningkatkan sikap positif terhadap belajar dan meningkatkan kemampuan mahasiswa untuk berpikir ilmiah, keterampilan eksperimental dan praktis (Celik, 2013).

Tinjauan literatur menunjukkan bahwa model siklus belajar dapat terintegrasi dan diperkaya dengan situasi mengajar lainnya. Tujuannya adalah untuk membuat perbandingan ilmiah dan untuk mengetahui cara mengajar yang lebih efisien. Dengan tujuan pemikiran yang sama, Toroslu (dalam Celik, 2013) menambahkan model mengajar 7E dengan unsurunsur pembelajaran berbasis kehidupan, yang membuat kontribusi yang signifikan terhadap keterampilan proses sains. Demikian juga Celik (2013) mengintegrasikan model pembelajaran 7E dengan instruksi berbantuan komputer.

Dalam penelitian selanjutnya peneliti memadukan pembelajaran sikus 7E dengan hypnoteaching. Langkah-langkah siklus belajar 7E menurut Eisencraft (Pitriati, 2014) adalah sebagai berikut:

1. Fase Elicit, dimaksudkan untuk mengidentifikasi pengetahuan awal mahasiswa, memastikan apakah mahasiswa sudah mengetahui pelajaran yang akan dipelajari.

2. Fase Engage, dimaksudkan untuk menarik perhatian atau membangkitkan minat dan motivasi mahasiswa terhadap konsep yang akan diajarkan dengan mengajukan pertanyaan, bercerita, memberikan demonstrasi, atau dengan menunjukkan suatu objek, gambar atau video.

3. Fase Explore, dimaksudkan memberikan kesempatan kepada mahasiswa untuk memperoleh pengetahuan dengan pengalaman langsung yang berhubungan dengan konsep yang akan dipelajari, dimana mahasiswa mengobservasi, mengisolasi variabel, merencanakan penyelidikan, menginterpretasikan hasil dan mengembangkan hipotesis dan mengorganisir kesimpulan dan bahan-bahan pembelajaran yang telah disediakan sebelumnya.

4. Fase Explain, mahasiswa memberikan penjelasan tentang konsep, memperkenalkan konsep-konsep, istilah dan meringkas hasil yang diperoleh pada fase eksplorasi. 
5. Fase Elaborate, mahasiswa diberikan kesempatan untuk menerapkan pengetahuan yang baru mereka temukan pada permasalahan-permasalahan yang berkaitan dengan contoh dari pelajaran yang dipelajari, misalnya memberikan latihan soal-soal dengan tingkat analisa yang lebih dalam pada mahasiswa.

6. Fase Evaluate, merupakan siklus lanjutan untuk mengevaluasi pengetahuan mahasiswa. Dengan menggunakan penilaian formatif untuk melihat perkembangan mahasiswa, perkembangan yang diinginkan dalam pemahaman mahasiswa tentang konsep-konsep, prinsip dan kemampuan menerapkan konsep tersebut.

7. Fase Extend adalah fase mahasiswa didorong untuk menghubungkan dan menjelaskan contoh penerapan konsep yang mereka pelajari dengan kehidupan sehari-hari.

Keberhasilan mahasiswa menjalankan langkah pembelajaran siklus 7E perlu dibantu dengan sugesti dan dorongan positif yang meyakinkan bahwa mahasiswa mampu menjalankan setiap langkah tersebut. Hypnoteaching membantu mahasiswa menjalankan langkah siklus 7E dengan semangat dan menyenangkan. Beberapa aspek hypnoteaching dapat digunakan adalah: 1) memulai mengajar dengan membuat mahasiswa fokus baik dengan games, bernyanyi bersama-sama, cerita inspiratif, maupun yeling (Focusing); 2) melakukan rileksasi dan imajinasi; 3) menyatakan sesuatu yang positif dari diri mahasiswa (Affirmation); 4) melakukan pengulangan kata-kata motivasi penuh inspiratif (Repeating) dan 5) sebelum pembelajaran berakhir, mahasiswa melakukan refleksi tentang pembelajaran yang dialaminya.

\section{METODE PENELITIAN}

Penelitian ini merupakan eksperimen semu karena dalam penelitian ini pengambilan subjek dalam suatu kelompok tidak dilakukan secara acak (Ary, Jacobs, \& Sorensen, 2010). Desain yang digunakan dalam penelitian eksperimen semu ini adalah nonequivalent controlgroup design (Creswell, 2012). Pemilihan subjek pada kelompok eksperimen maupun kelompok kontrol tidak dilakukan secara acak karena dalam pelaksanaannya subjek sudah berada dalam kelas tertentu. Tidak dibentuknya pengelompokan subjek dalam kelas baru secara acak agar tidak mengganggu jadwal maupun susunan kelas yang ada pada tempat pelaksanaan penelitian.

Metode penelitian kuantitatif digunakan untuk membandingkan pencapaian dan peningkatan kemampuan pemecahan masalah, koneksi, dan self-efficacy matematis dua kelompok mahasiswa yang mendapatkan perlakuan yang berbeda. Kelompok eksperimen diberi perlakuan khusus berupa pembelajaran Siklus 7E berbantuan Hypnoteaching (PSH) Prima, Vol. 3, No. 2, Juli 2019, 158-174. 
sedangkan kelompok kontrol mendapatkan pembelajaran konvensional (PK). Desain penelitian kuantitatif yang digunakan yaitu pretest-posttest control group design (Fraenkel, 1993; Ruseffendi, 2005).

Variabel bebas dalam penelitian ini yaitu pembelajaran Siklus 7E berbantuan Hypnoteaching (PSH) dan pembelajaran konvensional (PK). Variabel terikatnya yaitu kemampuan pemecahan masalah matematis, kemampuan koneksi matematis, dan self-efficacy matematis. Variabel pengontrol dalam penelitian ini terdiri dari pengetahuan awal matematis (tinggi, sedang, dan rendah). Pengetahuan awal matematis mahasiswa ditentukan berdasarkan pada rata-rata hasil tes mahasiswa dari tujuh mata kuliah matematika pada semeter sebelumnya.

Sampel penelitian diambil secara acak kelas untuk mendapatkan dua kelompok yaitu kelompok eksperimen dan kelompok kontrol. Selanjutnya, pada masing-masing kelompok dilakukan pretes $(\mathrm{O})$. Kelompok eksperimen diberikan perlakuan berupa pembelajaran Siklus 7E berbantuan hypnoteaching dan kelompok kontrol diberikan pembelajaran konvensional (tidak diberi perlakuan secara khusus). Setelah perlakuan pembelajaran, selanjutnya mahasiswa diberikan postes $(\mathrm{O})$. Secara singkat, desain penelitian ini digambarkan sebagai berikut:

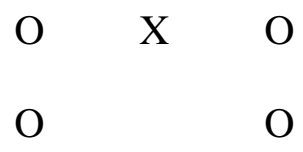

Gambar 3 Desain Penelitian

Keterangan:

$\mathrm{X}=$ Pembelajaran Siklus 7E berbantuan Hypnoteaching

$\mathrm{O}=$ Pretes $=$ Postes $($ Tes Kemampuan Koneksi Matematis

\section{HASIL DAN PEMBAHASAN}

Hasil

Tabel 1 memperlihatkan secara keseluruhan mahasiswa yang mendapatkan pembelajaran PSH menunjukkan pencapaian dan peningkatan kemampuan koneksi matematis yang lebih tinggi daripada mahasiswa yang mendapatkan pembelajaran PK. Hasil tersebut didukung oleh rerata pretes dan postesnya. Pada tabel tersebut nampak bahwa mahasiswa yang mendapatkan pembelajaran PSH menunjukkan rerata postes yang lebih besar daripada mahasiswa yang mendapatkan pembelajaran PK. Rerata postes keseluruhan 
mahasiswa yang mendapatkan pembelajaran PSH sebesar 43,42 sedangkan mahasiswa yang mendapatkan pembelajaran PK hanya sebesar 36,74.

Tabel 1. Statistika Deskriptif Data Kemampuan Koneksi Matematis Mahasiswa

\begin{tabular}{ccccccccc}
\hline \multirow{2}{*}{ Stat. } & \multicolumn{3}{c}{ PSH } & \multicolumn{6}{c}{ PK } \\
\cline { 2 - 9 } & Pretes & Postes & N-gain & $\boldsymbol{n}$ & Pretes & Postes & N-gain & $\boldsymbol{n}$ \\
$\overline{\boldsymbol{x}}$ & 10,44 & 31,68 & 0,55 & & 10,64 & 25,91 & 0,39 & 58 \\
$\boldsymbol{s}$ & 6,47 & 8,42 & 0,19 & & 5,18 & 7,19 & 0,15 & \\
\hline
\end{tabular}

Keterangan: Skor maksimal ideal 54

Statistika deskriptif data kemampuan koneksi matematis menunjukkan secara keseluruhan rerata pencapaian dan peningkatan kemampuan koneksi matematis mahasiswa yang mendapat pembelajaran PSH lebih besar daripada mahasiswa yang mendapat pembelajaran konvensional.

Secara keseluruhan, peningkatan kemampuan koneksi matematis mahasiswa yang mendapatkan pembelajaran PSH lebih besar dibandingkan mahasiswa yang mendapatkan pembelajaran PK. Peningkatan kemampuan koneksi matematis mahasiswa yang mendapatkan pembelajaran PSH tergolong sedang. Demikian juga peningkatan kemampuan koneksi matematis mahasiswa yang mendapatkan pembelajaran PK tergolong

Berdasarkan uji normalitas dan ujihomogenitas diketahui data peningkatan kemampuan koneksi matematis mahasiswa kelompok eksperimen (PSH) dan kelompok kontrol (PK) masing-masing berdistribusi normal dan mempunyai variansi data yang homogen. Oleh karena itu, untuk mengetahui ada atau tidak adanya perbedaan rerata kedua kelompok data tersebut, selanjutnya dianalisis dengan menggunakan statistik uji-t. Berikut ini adalah hipotesis yang diajukan untuk menguji peningkatan kemampuan koneksi matematis mahasiswa secara keseluruhan:

$\mathrm{H}_{0}$ : Peningkatan kemampuan koneksi matematis mahasiswa secara keseluruhan yang mendapat pembelajaran siklus 7E berbantuan hypnoteaching tidak lebih baik daripada mahasiswa yang mendapat pembelajaran konvensional.

$\mathrm{H}_{1}$ : Peningkatan kemampuan koneksi matematis mahasiswa secara keseluruhan yang mendapat pembelajaran siklus 7E berbantuan hypnoteaching lebih baik daripada mahasiswa yang mendapat pembelajaran konvensional.

Hasil analisis uji-t data peningkatan kemampuan koneksi matematis mahasiswa secara keseluruhan disajikan pada Tabel 2.

Prima, Vol. 3, No. 2, Juli 2019, 158-174. 
Tabel 2. Uji Perbedaan Peningkatan Kemampuan Koneksi Matematis berdasarkan Pembelajaran

\begin{tabular}{lllll}
\hline Pembelajaran & Rerata & $\mathbf{t}$ & $\begin{array}{l}\text { Sig. } \\
(\mathbf{1}-\text { tailed })\end{array}$ & $\mathbf{H}_{\mathbf{0}}$ \\
\hline PSH & 0,5504 & 4,695 & 0,000 & Ditolak \\
PK & 0,3929 & & & \\
\hline
\end{tabular}

Hasil uji-t di atas menghasilkan nilai probabilitas (sig.) yang kurang dari taraf signifikansi 0,05 yang ditetapkan, sehingga hipotesis nol ditolak. Dapat disimpulkan bahwa terdapat perbedaan yang signifikan antara peningkatan kemampuan koneksi matematis mahasiswa yang mendapatkan pembelajaran PSH dan mahasiswa yang mendapatkan pembelajaran PK. Berdasarkan hasil pengujian di atas dan nilai rerata peningkatan kemampuan koneksi matematis mahasiswa pada kedua kelompok pembelajaran tersebut, dapat disimpulkan bahwa secara keseluruhan peningkatan kemampuan koneksi matematis mahasiswa yang mendapat pembelajaran PSH lebih baik daripada mahasiswa yang mendapat pembelajaran konvensional.

\section{Pembahasan}

Hasil penelitian menunjukkan bahwa peningkatan kemampuan koneksi matematis mahasiswa yang mendapat pembelajaran PSH secara keseluruhan lebih baik daripada mahasiswa yang mendapat pembelajaran konvensional. Hasil ini sesuai dengan karakteristik pembelajaran siklus 7E berbantuan hypnoteaching. Tahap awal 7E elicit, engage dibantu focusing dan rileksasi membantu mahasiswa mengkoneksikan pengetahuan yang telah dimiliki sebeumnya dengan topik yang akan dipelajari. Begitu juga tahap explore, explain dan elaborate pada siklus7E dibantu dengan afirmasi pada hypnoteaching menguatkan mahasiswa dalam menggali dan menemukan konsep-konsep dalam matematika. Tahap evaluate dan extend melatih mahasiswa mengenali hubungan antar konsep matematika yang telah diketahuinya dengan yang baru dipelajari.

\section{SIMPULAN DAN SARAN}

\section{Simpulan}

Peningkatan kemampuan koneksi matematis mahasiswa yang mendapatkan pembelajaran PSH lebih baik daripada mahasiswa yang mendapatkan pembelajaran PK. Peningkatan kemampuan koneksi matematis mahasiswa yang mendapatkan pembelajaran PSH

Peningkatan Kemampuan Koneksi Matematis Mahasiswa Melalui Pembelajaran Model Siklus $7 E$ 
termasuk kategori sedang, begitu juga mahasiswa yang mendapatkan pembelajaran PK peningkatannya tergolong sedang.

\section{Saran}

Pembelajaran siklus 7E berbantuan hypnoteaching (PSH) dapat diterapkan dalam mengoptimalkan kemampuan koneksi matematis mahasiswa.

\section{DAFTAR PUSTAKA}

Ary, D., Jacobs, L.C., \& Sorensen, C.K. (2010). Introduction to research in education (8th ed.). Canada: Wadsworth.

Celik, H. (2013). The effect of the computer-aided 7e teaching model on students' science process skills, Mediterranean Journal of Educational Research, Issue 14a, Year 2013, pp. $926-932$

Creswell, J.W. (2012). Qualitative, quantitative, and mixed method approaches, Third Edition. Thousand Oaks California: Sage Publications.

Dale, R.A. (2014), Hypnosis and education. [Online]. Tersedia: http://eric.ed.gov/?id=ED087710. [3 Nopember 2014]

Departemen Pendidikan Nasional RI (2006). Permendiknas Nomor 22 Tahun 2006 Tentang Standar untuk Satuan Pendidikan Dasar dan Menengah, Jakarta: Depdiknas RI.

Eisenkraft, A. (2003). A proposed 7E model emphasizes "transfer of learning" and the important of eliciting prior understanding. The Science Teacher, Vol. 70, No. 6, Published by the National Science Teachers Association (NSTA).

Eisenkraft, A. (2003). Expanding the 5E model. In The Science Teacher (pp. 56-59). Arlington, VA: National Science Teachers Association (NSTA).

Fraenkel, J.C. \& Wallen, N.E. (1993). How to design and evaluate research in education. New York, McGraw-Hill, Inc.

Hajar, I. (2011), Hypnoteaching memaksimalkan hasil proses belajar-mengajar dengan hypnoterapi. Diva Press.

Hudojo, H. (2005). Pengembangan kurikulum dan pembelajaran matematika. Malang: UM Press.

Kementerian Pendidikan dan Kebudayaan (2014). Pedoman penyusunan capaian pembelajaran lulusan program studi.

Kocakaya, et.al. (2010). The effects of computer-assisted instruction designed according to 7e model constructivist learning on physics student teachers' achievement, concept

Prima, Vol. 3, No. 2, Juli 2019, 158-174. 
learning, self-efficacy perceptions and attitudes. Turkey Online Journal of Distance Education-TOJDE July Volume: 11 Number: 3 Article 12

Kurniawati, L. (2014). Meningkatkan kemampuan berpikir intuitif-reflektif, pembuktian matematis dan disposisi mahasiswa melalui pembelajaran berbasis masalah dengan metode hypnoteaching. Disertasi. Program Pascasarjana Universitas Pendidikan Indonesia.

Lestari, K.E. (2013). Implementasi brain-based learning untuk meningkatkan kemampuan koneksi dan berpikir kritis matematis siswa SMP. Tesis. Program Pascasarjana Universitas Pendidikan Indonesia.

Mecit, O. (2006). The effects of $7 E$ learning cycle model on the improvement of fifth grade students' critical thinking skills. Dissertation: The Graduate School Of Natural And Applied Sciences of Middle East Technical University.

NCTM. (2003). Program for initial preperation of mathematics specialists. [Online]. Tersedia: http://www.ncate.org/ProgramStandards/NCTM/NCTMStandards.pdf. $\quad[4$ Februari 2014].

Noer, Muhammad. (2010). Hypnoteaching for success learning. Pedagogia Pustaka Insan Madani.

Pitriati. (2014). Pengaruh penerapan model learning cycle $7 E$ terhadap peningkatan kemampuan penalaran dan kemampuan komunikasi matematis siswa SMP. Tesis. Program Pascasarjana Universitas Pendidikan Indonesia.

Ramdani, Y. (2013). Pembelajaran dengan scientific debate untuk meningkatkan kemampuan komunikasi, penalaran, dan koneksi matematis mahasiswa dalam konsep integral. Disertasi. Program Pascasarjana Universitas Pendidikan Indonesia.

Ramdani, Y. (2012). Pengembangan instrumen dan bahan ajar untuk meningkatkan kemampuan komunikasi, penalaran, dan koneksi matematis dalam konsep integral. Jurnal Penelitian Pendidikan Vol. 13 No. 1, April 2012

Sumarmo, U. (2003). Kumpulan makalah: berpikir dan disposisi matematik serta pembelajarannya. Sekolah Pascasarjana Universitas Pendidikan Indonesia. Bandung. (2014). Advanced mathematical thinking dan habit of mind mahasiswa. Sekolah Pascasarjana Universitas Pendidikan Indonesia. Bandung.

Susilawati. (2010). Penerapan model siklus belajar hipotetik deduktif 7E. untuk meningkatkan penguasaan konsep dan ketrampilan proses sains siswa sma pada konsep pembiasan cahaya. Disertasi SPS UPI Bandung.

Peningkatan Kemampuan Koneksi Matematis Mahasiswa Melalui Pembelajaran Model Siklus $7 E$ 
Tim Kurikulum Prodi S1 Dari Indoms. (2014). Laporan rekomendasi capaian pembelajaran serta struktur kurikulum minima. Jakarta: Indo-MS. 